\title{
PREFERENSI NASABAH MEMILIH BANK SYARIAH \\ DILIHAT DARI ASPEK KARAKTERISTIK NASABAH
}

\author{
Oleh : \\ Julian. S.Pd., M.Sy \\ STIE Dr. Khez Muttaqien Prodi Akuntansi dan Prodi Ilmu Ekonomi dan Keuangan \\ Islam UPI \\ Email julian@upi.edu \\ Ropi Marlina. SE., M.Sy \\ STIE Dr. Khez Muttaqien Prodi Akuntansi \\ Emailropimarlina@gmail.com
}

\begin{abstract}
Abstrak
Tulisan ini mencoba memaparkan hasil studi lapangan dengan menyebarkan kuisioner kepada para nasabah bank Muamalat terkait preferensi nasabah memilih bank Syariah melalui pendekatan karakteristik responden.Adapun responden yang diteliti pada penelitian ini terdiri dari nasabah beberapa kantor kas cabang bank syariah yang ada di kota bandung, yaitu terdiri dari kantor kas cabang Geger Kalong Girang, kantor kas cabang Cihampelas, kantor kas cabang Dago, kantor kas cabang Citarum, serta pusatnya yaitu di kantor cabang Buah Batu.Metode yang digunakan dalam penelitian ini adalah survey explanatori, yaitu metode dengan pendekatan mengungkap fakta-fakta baru dilapangan. Secara umum dalam penelitian ini mengungkap terkait karakteristik responden yang paling positif penilainya terhadap bank syariah.
\end{abstract}

\section{LATAR BELAKANG}

Perkembangan perbankan syariah di Indonesia tidak terlepas dari system perbankan di Indonesia secara umum. Sistem perbankan syariah juga diatur dalam Undang-undang No. 21 tahun 2008 dimana Bank Umum adalah bank yang melaksanakan kegiatan usaha secara konvensional atau berdasarkan prinsip syariah yang kegiatannya memberikan jasa dalam lalu lintas pembayaran.
Keberadaan Bank Syariah diharapkan mampu mewujudkan sistem perbankan yang kompetitif, efisien, dan memenuhi prinsip kehati-hatian serta mampu mendukung sektor riil secara nyata melalui kegiatan pembiayaan berbasis bagi hasil dan transaksi riil dalam kerangka keadilan, tolong menolong dan menuju kebaikan guna mencapai kemaslahatan masyarakat. Keberhasilan dan 
kelanggengan Bank berdasarkan syariah ini sangat diharapkan oleh umat Islam sehingga mampu merealisasikan tujuantujuannya. Oleh karena itu agar Bank ini dapat bertahan hidup dan terus berkembang dengan baik serta memiliki karakteristik yang sehat sesuai dengan ketetapan yang dikeluarkan oleh bank indonesia, maka perlu dukungan lebih dari umat Islam.

Berangkat dari kesuksesan Bank Muamalat, berkembang pula lembagalembaga keuangan Islam lainnya seperti Baitul Mal Wat-Tamwil, Pasar Modal Syariah, Reksadana Syariah, Pegadaian Syariah, Asuransi Syariah, Lembaga Penjaminan Syariah dan lembaga-lembaga lain yang dijalankan dengan prinsip-prinsip Syariah. Dibandingkan dengan laju pertumbuhan volume usaha perbankan nasional $20 \%$, industri perbankan syariah nasional bertumbuh rata-rata $56 \%$ per-tahun selama 2004-2008 (Direktorat Perbankan Syariah, 2010).

Sejak diterbitkannya UndangUndang (UU) No. 21 Tahun 2008 tentang Perbankan Syariah sebagai landasan legal formal yang secara khusus mengatur berbagai hal mengenai perbankan syariah di tanah air, maka kecepatan pertumbuhan industri ini diperkirakan akan melaju lebih kencang lagi. Hal ini terlihat dari indikator penyaluran pembiayaan yang mencapai rata-rata pertumbuhan sebesar $36,7 \%$ pertahun dan indikator penghimpunan dana dengan rata-rata pertumbuhan mencapai 33,5\% pertahun untuk tahun 2007 sampai dengan tahun 2008. Berdasarkan data tersebut, maka bisa dikatakan bahwa perbankan syariah menegalami keberhasilan yang luar biasa. Akan tetapi menurut Ali (2007) keberhasilan tidak diimbangi dengan market share industri perbankan syariah di Indonesia.hal yang sama diutarakan oleh Ketua Panja RUU Perbankan Syariah, Endin AJ Soefihara. Pasalnya, pangsa pasar syariah saat ini baru sekitar 2 persen dari sekira Rp1.600 triliun pasar bank konvensional. Padahal sbelumnya, menurut Deputi Guberbur Bank Indonesia, Siti Fadjriah, menyatakan bahwa target pangsa pasar untuk bank syariah tahun 2008 adalah 5\%. Berdasarkan datadata tersebut menimbulkan pertanyaan baru, mengapa perkembangan Bank Syariah di Indonesia belum memberikan hasil yang signifikan atau masih di bawah market Share 5\%, padahal mayoritas dari masyarakat Indonesia adalah muslim?

Tulisan ini mencoba memaparkan hasil studi lapangan dengan menyebarkan kuisioner kepada para nasabah bank Muamalat terkait preferensi nasabah memilih bank Syariah. Responden yang diteliti pada penelitian ini terdiri dari 
beberapa kantor kas cabang bank syariah yang ada di kota bandung, yaitu terdiri dari kantor kas cabang Geger Kalong Girang, kantor kas cabang Cihampelas, kantor kas cabang Dago, kantor kas cabang Citarum, serta pusatnya yaitu di kantor cabang Buah Batu. Karena jumlah nasabahnya yang banyak, maka yang dijadikan sampel penelitian ini sebanyak 95 orang. Gambaran umum mengenai nasabah Bank Muamalat Indonesia cabang kota Bandung pada penelitian ini akan diuraikan melalui data tentang jenis kelamin, usia, pendidikan, pekerjaan, pernah pesantren, dan lama menjadi nasabah bank Muamalat Indonesia.

Nilai rata-rata tiap variabel berdasarkan data ordinal memiliki arti bahwa semakin besar nilai koefisien, berarti responden memiliki penilaian yang semakin positif (bagus) terhadap variable tersebut. Hal ini berhubungan dengan pemberian skor kuesioner, dimana skor jawaban yang semakin besar akan semakin bernilai positif.

Responden yang diteliti pada penelitian ini terdiri dari beberapa kantor

\section{KAJIAN PUSTAKA}

\section{Pengertian Perbankan Syariah}

Ada beberapa definisi tentang Bank Syariah atau Bank Islam, diantaranya: Antonio mendefinisikan bahwa Bank Islam kas cabang bank syariah yang ada di kota bandung, yaitu terdiri dari kantor kas cabang Geger Kalong Girang, kantor kas cabang Cihampelas, kantor kas cabang Dago, kantor kas cabang Citarum, serta pusatnya yaitu di kantor cabang Buah Batu. Karena jumlah nasabahnya yang banyak, maka yang dijadikan sampel penelitian ini sebanyak 95 orang. Gambaran umum mengenai nasabah Bank Muamalat Indonesia cabang kota Bandung pada penelitian ini akan diuraikan melalui data tentang jenis kelamin, usia, pendidikan, pekerjaan, pernah pesantren, dan lama menjadi nasabah bank Muamalat Indonesia.

Selain itu, dalam penelitian ini penulis membagi tiga criteria yaitu rendah, sedang dan tinggi. Hal ini didasarkan pada skor tertinggi di tambah skor terendah kemudian di bagi tiga. Dengan demikian akan diperoleh skor 44 yang kemudian oleh penulis jadikan sebagai patokan bahwa skor di bawah 44 dikatakan rendah. Kemudian skor antara 45-88 dijadikan kriteria sedang, selanjutanya diatas skor 88 oleh penulis dijadikan patokan skor tinggi.

adalah Bank yang beroperasi sesuai dengan prinsip-prinsip Syariat Islarn atau Bank yang tata cara beroperasinya mengacu 
kepada ketentuan Al Qur'an dan Hadits (Antonio, 2001)

Adapun General Secretary of the OIC's(Organitation of the Islamic Conference) mendefinisikan Bank Islam sebagai berikut: (Sarkar, 1999)

"An Islamic bank is a financial institution whose status, rules and procedures expressly state its commitment to the principle of Islamic Shariah and to the banning of the receipt and payment of interest on any of its operations ".

\section{Pengertian Pengambilan Keputusan}

Terdapat beberapa pengertian yang mengemukakan tentang perilaku konsumen. Untuk lebih jelasnya akan dikemukakan beberapa pendapat mengenai pengertian prilaku konsumen, yang antara lain:

Menurut Engel (1994) Perilaku konsumen adalah tindakan yang langsung terlibat untuk mendapatkan, mengkonsumsi, dan menghabiskan produk dan jasa, termasuk proses keputusan yang mendahului dan mengikuti tindakan ini. Kemudian Philip Kotler (2001) menyatakan bahwa proses pengambilan keputusan pembelian merupakan bagian tak terpisahkan dari model perilaku pembeli dimana hal tersebut umumnya dipengaruhi oleh faktor budaya, sosial, kepribadian serta faktor psikologis.

Adapun menurut David I.London dan Albert J.Dello Bitta dalam Anwar
Prabu Mangkunegara mendefinikan perilaku konsumen adalah tindakantindakan proses dan hubungan sosial yang dilakukan oleh individu, kelompok atau organisasi dalam mendapatkan, menggunakan suatu produk.

Sedangkan menurut J.F. Engel yang di kutif dari Bayu Swasta dan Hani Handoko (1997), Perilaku Konsumen merupakan kegiatan-kegiatan individu yang secara langsung terlibat dalam mendapatkan dan mempergunakan barang-barang dan jasa, termasuk di dalamnya proses pengambilan keputusan dan persiapan dan penentuan kegiatan-kegiatan tersebut. Kemudian pengambilan keputusan sendiri menurut Sondang Siagian (1997) mengungkapkan bahwa "suatu keputusan dapat dikatakan sebagai keputusan yang baik jika memenuhi empat persyaratan, yaitu rasional, logis, realistis, dan pragmatis".

Morgan \& Cerullo mengungkapkan Keputusan ialah sebuah kesimpulan yang dicapai sesudah dilakukan pertimbangan, yang terjadi setelah satu kemungkinan dipilih, sementara yang lain dikesampingkan. Adapun yang dimaksud dengan pertimbangan adalah menganalisis beberapa kemungkinan /alternatif sesudah itu dipilih satu diantaranya (Salusu, 1996). 
Sedangkan menurut An nabhani (2001)pengambilan keputusan merupakan bagian dari perbuatan manusia. Sedangkan setiap dilakukannya suatu perbuatan, maka sudah barang tentu setiap orang memiliki tujuan atas perbuatan yang dilakukannya. Tujuan inilah yang biasa disebut qimatul 'amal (nilai perbuatan). Karena itu, suatu hal yang pasti bahwa setiap perbuatan memiliki nilai tertentu yang ingin dicapai oleh seseorang tatkala ia melakukannya. Kalau tidak, tentulah perbuatan itu akan siasia.

Adapun nilai tujuan suatu perbuatan tersebut menurut An nabhani diantaranya (2001)nilai suatu perbuatan yang bisa berupa nilai materi, seperti aktivitasaktivitas di bidang perdagangan, pertanian, industri dan sejenisnya. Maka, maksud dilakukannya perbuatan itu adalah untuk mendapatkan hasil berupa materi, yaitu memperoleh keuntungan. Nilai ini memiliki peranan tersendiri dalam kehidupan.

\section{PEMBAHASAN}

\section{Karakteristik Responden Berdasarkan Jenis Kelamin}

Distribusi responden nasabah Bank Muamalat Indonesia berdasarkan jenis kelamin, dapat dilihat dalam tabel berikut ini :

Deskripsi Jenis Kelamin Responden

\begin{tabular}{|l|c|c|}
\hline \multicolumn{1}{|c|}{ Jenis kelamin } & Frekuensi & Persentase \\
\hline Laki-laki & 44 & $46 \%$ \\
\hline Perempuan & 51 & $54 \%$ \\
\hline Jumlah & 95 & $100 \%$ \\
\hline
\end{tabular}

Sumber: data diolah dari hasil penelitian

Berdasarkan tabel di atas, diketahui bahwa dari seluruh responden yang menjadi objek sampel nasabah bank syariah yang berjumlah 95 orang responden, yang berjenis kelamin laki-laki adalah sebanyak 44 orang responden (46\%), sedang yang berjenis kelamin wanita adalah sebanyak 51 orang (54\%).

Berdasarkan hasil penelitian yang penulis lakukan di dapat hasil bahwa kenederungan laki laki untuk memilih bank syariah lebih tinggi dibandingkan dengan perempuan. Hal ini dibuktikan dengan data hasil responden laki-laki dengan kecenderungan rata-rata untuk memilih bank syariah sebesar 55,21.Sedangkan skor tertinggi dari responden perempuan dengan kecenderungan rata-rata untuk memilih bank syariah sebesar 54,2. Dengan demikian berdasarkan karateristik jenis 
kelamin responden, laki-laki memiliki penilaian yang lebih positif (baik) terhadap pengambilan keputusan memilih bank syariah.

\section{Karakteristik Responden Berdasarkan Usia}

Usia merupakan salah satu faktor yang penting ketika kita akan memperoeh gambaran terkait objek suatu penelitian. Hal in karena usia pada umumnya akan linier dengan tingkat kematangan untuk menentukan sikapnya. termasuk diantaranya dalam memilih tempat dia menyimpan dana. Usia nasabah pada bank muamalat Indonesia cabang kota bandung yang pada penelitian ini disajikan pada tabel sebagai berikut :

Deskripsi Usia Responden

\begin{tabular}{|l|c|c|}
\hline \multicolumn{1}{|c|}{ Umur } & Frekuensi & Persentase \\
\hline Di bawah 25 & 39 & $41 \%$ \\
\hline $26-35$ & 27 & $28 \%$ \\
\hline $36-45$ & 16 & $17 \%$ \\
\hline $46-55$ & 12 & $13 \%$ \\
\hline Di atas 56 & 1 & $0,01 \%$ \\
\hline Jumlah & 95 & $100 \%$ \\
\hline
\end{tabular}

Sumber: data diolah dari hasil penelitian

Berdasarkan tabel di atas, diketahui bahwa dari seluruh responden yang menjadi objek sampel nasabah bank syariah yang berjumlah 95 orang responden, yang berusia kurang dari 25 tahun adalah sebanyak 39 orang responden (41\%), 27 orang diantaranya (28\%) berusia antara 26 - 35 tahun, 16 orang (17\%)berusia antara 36-45 tahun, 12 orang (13\%)berusia antara 46-55 tahun sedang sisanya yaitu 1 orang $(0,01 \%)$ berusia lebihdari 56 tahun.

Berdasarkan tabel di atas, diketahui bahwa nilai rata-rata nasabah bank Muamalat Indonesia berdasarkan karakteristik usia sebagai berikut; dari jumlah keseluruhan responden berdasarkan karakteristik usia 25 tahun ke bawah yang terkategori skor tertingginya yaitu sebesar 54,44 . Adapun skor tertinggi dari responden berdasarkan karakteristik usia 26-35ratarata kecenderungan untuk memilih bank syariah sebesar 54,75. Kemudian skor tertinggi dari responden berdasarkan karakteristik usia 36 tahun ke yaitu sebesar 55,165. Dengan demikian berdasarkan karateristik usia responden, usia 36 tahun ke atas memiliki penilaian yang lebih 
positif (baik) terhadap pengambilan keputusan memilih bank syariah.

\section{Karakteristik Responden Berdasarkan Pendidikan}

Pendidikan merupakan salah satu faktor penting bagi nasabah bank syariah. Karena tingkat pendidikan akan mempengaruhi pola pikir seseorang dalam memutuskan pilihan terbaik dalam melakukan aktivitasnya. Begitu pula dengan nasabah, nasabah yang memiliki pendidikan tinggi dan wawasan yang luas akan lebih berfikir rasional dan bijak untuk menentukan suatu pilihan, sehingga akan bisa mengambil pilihan yang terbaik. Tingkat pendidikan nasabah pada bank muamalat Indonesia cabang kota bandung pada penelitian ini disajikan pada tabel berikut :

Deskripsi Pendidikan Responden

\begin{tabular}{|c|c|c|}
\hline Pendidikan & Jumlah & Keterangan \\
\hline Dibawah SMA & 2 & \\
\hline SMA/SMK/MAN & 35 & \\
\hline D1-D3 & 10 & $\begin{array}{l}\text { Terdiri dari berbagai jurusan diantaranya: } \\
\text { PGTK,admnistrasi, perkantoran, ekonomi, } \\
\text { pendidikan,Teknik kimia,bahasa Arab, Bisnis } \\
\text { international, akuntansi }\end{array}$ \\
\hline S1 & 33 & $\begin{array}{l}\text { jurusan pendidikan ekonomi, Informatika, Filsafat, } \\
\text { Pend akuntansi, PBA, matematika, Peternakan, pend } \\
\text { Fisika, Public Administrasi }\end{array}$ \\
\hline $\mathrm{S} 2$ & 44 & $\begin{array}{l}\text { pertambangan, MPI, Pend Bahasa Inggris, Adpend, } \\
\text { Publik Manegemen }\end{array}$ \\
\hline S3 & 4 & \\
\hline
\end{tabular}

Sumber: data diolah dari hasil penelitian

Berdasarkan tabel 4.3 dapat dilihat 2 orang responden atau $2,1 \%$ di bawah lulusan SMA, 35 orang atau $37 \%$ menempuh pendidikan hingga SMA/Sederajat, 10 orang atau $10,5 \%$ menempuh pendidikan D1-D3 dengan terdiri dari berbagai jurusan diantaranya; PGTK, Admnistrasi Perkantoran, Ekonomi, Pendidikan, Teknik kimia, Bahasa Arab, Bisnis International dan Akuntansi, 33 orang atau $35 \%$ menempuh pendidikan S1 yang terdiri dari jurusan Pendidikan 
Ekonomi, Informatika, Filsafat, dari jumlah keseluruhan responden Pendididkan Akuntansi, PBA, Matematika, berdasarkan karakteristik pendidikan SMA Peternakan, Pendididkan Fisika, Public ke bawah yang terkategori skor tertingginya Administrasi. 44 orang atau $46 \%$ yaitu sebesar 54,8. Selanjutnya dengan menempuh pendidikan S2 yang diri dari karateristik responden pendidikan D1-D3, jurusan Pertambangan, MPI, Pendidikan skor tertinggi sebesar 53,8. Sedangkan Bahasa Inggris, Administrasi Pendidikan, dengan karateristik responden pendidikan Publik Manegemen dan sisanya 4 orang $\mathrm{S} 1$ ke atas, rata-rata skor menempuh pendidikan hingga S3. Dari tertingginyasebesar 55,42. Dengan tabel 4.3 diatas, dapat diketahui bahwa demikian berdasarkan karateristik tingkat pendidikan di nasabah bank pendidikan S1 ke atas memiliki penilaian Muamalat Indonesia sudah cukup tinggi.

Untuk mempermudah pengklasifikasian, maka dalam pembahsan yang lebih positif (baik) terhadap pengambilan keputusan memilih bank syariah.

karakteristik Pendidikan nasabah, oleh penulisdi bagi kedalam 3 kategori; yaitu nasabah yang berpendidikan SMA ke bawah, Nasabah berpendidikan D1- D3, dan Nasabah yang berpendidikan S1 ke atas.

Berdasarkan hasil penelitian, diketahui bahwa nilai rata-rata nasabah Bank Muamalat Indonesia berdasarkan Karakteristik Responden Berdasarkan Pekerjaan

Hasil penelitian yang telah dilakukan ternyata dari 95 nasabah maka peneliti mengklasifikasikan menjadi 4, yaitu terdiri dari; PNS, Karyawan swasta, Wiraswasta/IRT dan Pelajar/mahasiswa, data lebih lengkapnya sebagai berikut; karakteristik pendidikan sebagai berikut;

Deskripsi Jenis Pekerjaan Responden

\begin{tabular}{|l|c|l|}
\hline \multicolumn{1}{|c|}{ Pekerjaan } & Jumlah & \multicolumn{1}{c|}{ Keterangan } \\
\hline PNS & 20 & guru, dosen, TNI AD, \\
\hline Karyawan & 29 & pabrik, guru honorer, perusahaan \\
\hline Wiraswasta dan IRT & 24 & \\
\hline pelajar/mahasiswa & 22 & jurusan ekonomi, akuntansi, fisika, biologi \\
\hline
\end{tabular}

Sumber: data diolah dari hasil penelitian 
Berdasarkan tabel di atas, diketahui bahwa dari seluruh responden yang menjadi objek sampel nasabah bank syariah yang berjumlah 95 orang responden, 20 yang memiliki pekerjaan sebagai pegawai negeri sipil $(21 \%), 29$ orang $(30,5 \%)$ berprofesi sebagai karyawan swasta, 24 orang diantaranya $(25 \%)$ bekerja sebagai wiraswasta, 22 orang (23\%) adalah pelajar atau mahasiswa.

Berdasarkan hasil penelitian diketahui bahwa nilai rata-rata nasabah Bank Muamalat Indonesia berdasarkan karakteristik pekerjaan sebagai berikut; dari jumlah keseluruhan responden berdasarkan karakteristik pekerjaan Pelajar/ Mahasiswa yang terkategori skor tertingginya yaitu sebesar 53,4. Selanjutnya dengan karateristik responden pekerjaan Wiraswasta sebanyak 24 responden dengan rincian 19 responden masuk terkategori sedang dengan jumlah rata-rata skor sebesar 45,52 dan 5 responden terkategori tinggi dengan jumlah rata-rata skor sebesar 55,4. Selanjutnya dengan karateristik responden pekerjaan Karyawan swasta sebanyak 29 responden dengan rincian 1 orang terkategori rendah yaitu sebesar 45 , Serta 17 responden masuk terkategori sedang dengan jumlah rata-rata skor sebesar 44,58 dan 11 responden terkategori tinggi dengan jumlah rata-rata skor sebesar 54,09.Selanjutnya dengan karateristik responden pekerjaan PNS sebanyak 20 responden dengan rincian 15 responden masuk terkategori sedang dengan jumlah rata-rata skor sebesar 44,33 dan 5 responden terkategori tinggi dengan jumlah rata-rata skor sebesar 57,8. Dari uraian diatas maka jika diklasifikasikan yang paling positif penilaiannya terhadap bank syariah adalah nasabah yang bekerja sebagai PNS, ini di buktikan dengan rata rata skor nya paling tinggi atau paling positif.

\section{Karakteristik Responden Berdasarkan}

\section{Lama Menjadi Nasabah}

Berdasarkan hasil penelitian, lama menjadi nasabah bank syariah terlihat dalam tabel 4.5 berikut:

Deskripsi Responden Lama menjadi nasabah

\begin{tabular}{|l|l|c|}
\hline $\begin{array}{l}\text { Lama menjadi } \\
\text { nasabah }\end{array}$ & Frekuensi & Persen \\
\hline Di bawah 2 thn & 55 & $58 \%$ \\
\hline 2-5 tahun & 31 & $33 \%$ \\
\hline lebih dari 5 tahun & 9 & $9,5 \%$ \\
\hline
\end{tabular}

Sumber: data diolah dari hasil penelitian 
Dari data di atas terlihat bahwa 55 orang atau $58 \%$ responden sudah menjadi nasabah Bank Muamalat Indonesia, antara 2-5 tahun 31 orang atau 33\% responden sudah menjadi nasabah bank Muamalat Indonesia dan sisanya yaitu 9 orang atau 9,5\% responden responden sudah menjadi nasabah bank Muamalat Indonesia lebih dari 5 tahun.

Berdasarkan tabel di atas, diketahui bahwa nilai rata-rata nasabah Bank Muamalat Indonesia berdasarkan karakteristik lama menjadi nasabah sebagai berikut; Dari jumlah keseluruhan responden lama menjadi nasabah di bawah 2 tahun adalah 55 orang. Adapun yang terkategori skor sedang sebanyak 37 responden dengan rata-rata 44,57. Hal ini menunjukan kecenderungan nasabah dalam memilih bank syariah dari 55 responden dengan skor rata-rata sebesar 44,57. Sedangkan skor tertinggi dari responden dengan karateristik di bawah 2 tahun menjadi nasabah di bawa sebanyak 16 responden dengan kecenderungan rata-rata untuk memilih bank syariah sebesar 53,69. Dari jumlah keseluruhan responden lama menjadi nasabah antara 2-5 tahun yang terkategori skor sedang sebanyak 31 responden.

Karakteristik Responden Berdasarkan Pendidikn Pesantren
Adapun yang terkategori skor sedang sebanyak 18 dengan rata-rata 45,06. Hal ini menunjukan kecenderungan nasabah dalam memilih bank syariah dari 18 responden dengan skor rata-rata sebesar 45,06. Sedangkan skor tertinggi dari responden dengan karateristik lama menjadi nasabah sebanyak 13 responden dengan kecenderungan rata-rata untuk memilih bank syariah sebesar 55,9. Adapun dengan responden lama menjadi nasabah diatas 5 tahun, jumlah keseluruhan sebanyak 9 responden dengan rincian 7 orang masuk kategori sedang dengan jumlah rata-rata skor sebesar 45,58. Hal ini berarti kecenderungan nasabah dalam memilih bank syariah dari 7 responden dengan skor rata-rata sebesar 45,58. Sedangkan skor tertinggi dari responden nasabah diatas 5 tahun sebanyak 2 resonden dengan kecenderungan rata-rata untuk memilih bank syariah sebesar 54,5. Dengan demikian berdasarkan karateristik lama menjadi nasabah, maka nasabah antara 2-5 tahun memiliki penilaian yang lebih positif (baik) terhadap pengambilan keputusan memilih bank syariah.

Berdasarkan hasil penelitian, lama menjadi nasabah bank syariah terlihat dalam tabel berikut: 
Deskripsi pernah mengikutiPendidikan Pesantren

\begin{tabular}{|l|l|l|}
\hline \multicolumn{1}{|c|}{ Karakteristik } & \multicolumn{1}{|c|}{ Frekuensi } & \multicolumn{1}{c|}{ Persentase } \\
\hline Pernah Pesantren & 28 & $29 \%$ \\
\hline Tidak Pernah & 67 & $71 \%$ \\
\hline Jumlah & 95 & $100 \%$ \\
\hline
\end{tabular}

Sumber: data diolah dari hasil penelitian

Berdasarkan tabel di atas, diketahui bahwa dari seluruh responden yang menjadi objek sampel nasabah bank syariah yang berjumlah 95 orang responden, yang pernah mengikuti pendidikan pesantren adalah sebanyak 28 orang responden (29\%), sedang yang tidak pernah adalah sebanyak 67 orang $(71 \%)$.

Dari hasil penbaran diatas dapat diketahui bahwa nilai rata-rata nasabah bank Muamalat Indonesia berdasarkan karakteristik pernah mengkuti pesantren sebagai berikut; dari jumlah keseluruhan responden yang pernah sebesar 28 responden dan yang terkategori skor sedang dari nasabah yang pernah sebanyak 13 responden dengan rata-rata 43,2. Hal ini menunjukan kecenderungan nasabah dalam memilih bank syariah dari 13 responden dengan skor rata-rata sebesar 43,2. Sedangkan skor tertinggi dari responden laki-laki sebanyak 15 orang dengan kecenderungan rata-rata untuk memilih bank syariah sebesar 55,4. Adapun dengan responden yang tidak pernah pendidikan pesantren, jumlah keseluruhan sebanyak 67 orang dengan rincian 50 orang masuk kategori sedang dengan jumlah rata-rata skor sebesar 45,26. Hal ini berarti kecenderungan nasabah dalam memilih bank syariah dari 50 responden dengan skor rata-rata sebesar 45,26. Sedangkan skor tertinggi dari responden yang tidak pernah pesantren sebanyak 17 orang dengan kecenderungan rata-rata untuk memilih bank syariah sebesar 55,06. Dengan demikian berdasarkan karateristik pernah mengikuti pesantren, yang pernah mengikuti pesantren memiliki penilaian yang lebih positif (baik) terhadap pengambilan keputusan memilih bank syariah.

Dengan demikian hasil penelitian ini memperkuat teori yang yang digunakan. Dengan kata lain penelitian yang dilakukan penulis secara umum sama dengan penelitian-penelitian sebelumnya yaitu sejalan dengan teori yang digunakan seperti dari Kotler menyebutkan perilaku konsumen dipengaruhi oleh faktor budaya, sosial, kepribadian serta faktor psikologis. 
Secara umum yang menarik dalam penlitian ini adalah responden kebanyakan mengenyam pendidikan rata-rata diatas SMA/SMK. Hal ini jelas berpengaruh karena pendidikan akan membentuk persepsi orang terhadap sesuatu yang akan dia gunakan.

Hasil pengujian crosstab analysis Bank Indonesia kerjasama dengan Center for Banking Research Universitas Andalaspada tahun 2007memperlihatkan bahwa terdapathubungan signifikan antara tingkatpendidikan, usia, dan jenis

\section{KESIMPULAN DAN SARAN}

Berdasarkan hasil penelitian yang penulis paparkan, maka dapat disimpulkan sebagai berikut;

a. Jenis Kelamin laki-laki lebih positif pengaruhnya terhadap pengambilan keputusan nasabah dalam memilih bank Syariah di bank mumalat Indonesia cabang Kota Bandung. Hendaknya bagi BMI meningkatkan sosilasiasi terhadap nasabah perempuan. Hal itu di sebabkan masyarakat bandung lebih di dominasi perempuan.

b. Karakteristik usia nasabah diatas 36 lebih positif pengaruhnya terhadap pengambilan keputusan nasabah dalam memilih bank Syariah di bank mumalat pekerjaandengan tipe bank yang dipilih olehresponden (Harif, 2007). Dengandasar bahwa kelompok pendidikan tinggilebih didominasi oleh responden banksyariah, dapat dinyatakan bahwaresponden yang memilih bank syariahmemiliki tingkat pendidikan relatif lebihtinggi.

Secaraumum kelompok usia responden padabank syariah relatif lebih muda yaitu rata-rata 15-35 tahun,dimana frekuensi kelompok usia yangmendominasi berada pada kisaran umur15 hingga 35 tahun (sebanyak 66responden).

Indonesia cabang Kota Bandung. Dari hasil penelitian ini hendaknya BMI menyasar pula segmen usia 25 kebawah dan usia 36-35 karena mereka merupakan pasar potensial.

c. Karakteristik Pendidikan nasabah yang berpendidikan di atas S1 lebih positif pengaruhnya terhadap pengambilan keputusan nasabah dalam memilih bank Syariah di bank mumalat Indonesia cabang Kota Bandung. Hendak bagi BMI meningkat sosilasiasi tehadap nasabah yang lainnya seperti menyisir kalanga pelajar atau lulusan di bawah SMA dan D3. Mengingat masyarakat kota bandung yang berpendidikan di 
bawah SMA dan D1-D3 jumlahnya sangat banyak.

d. Karakteristik Pekerjaan PNS lebih positif pengaruhnya terhadap pengambilan keputusan nasabah dalam memilih bank Syariah di bank mumalat Indonesia cabang Kota Bandung di bandingkan dengan Wiraswasta, Karyawan dan Pelajar/mahasiswa. Hendak bagi BMI meningkat sosilasiasi tehadap nasabah yang lainnya terutama wiraswasta yang merupakan pasar potensial bagi BMI. Mengingat pertumbuhan wiraswasta di kota bandung sangat tinggi. e. Karakteristik pernah mengikui pendidikan pesantren lebih positif pengaruhnya terhadap pengambilan keputusan nasabah dalam memilih bank syariah di bank mumalat Indonesia cabang Kota Bandung. Hal ini berimplikasi pada pesantrean sangat baik di jadikan sebagai pangsa pasar perbankan syariah. Namun demikian hendak bagi BMI meningkat sosilasiasi terhadap masyarakat non pesantren. Apalagi mayoritas masyarakat di kota bandung heterogen, sehingga segmentasi masyarakat yang non pesantren lebih dominan. 


\section{DAFTAR PUSTAKA}

Ahmad, S. (2004). Islamic Banking and Financing in the Contemporary Wolrd, Disertation. diakases melalui : htp.//www..xlri-dubai-net/.

Ali, Hasan. (2007). 2007: Tahun Pecepatan Industri Perbankan Syariah. Website Pusat Komunikasi Ekonomi Syariah (PKES)

Antonio Muhammad Syfe'i. (2001). Bank Syariah Wacana Ulama dan Cendekiawan. Bogor. Tazkia Institute.

An Nabhani, Taqiyudin. (2001). Peraturan Hidup dalam Islam. Al Azhar Press. Bogor.

Basu Swasta dan T. Hani Handoko. 1997. Manajemen Pemasaran: Analisa Perilaku Konsumen. Yogyakarta: Edisi pertama, BPFE.

Bjorklund, Irene. (2004). Islamic Banking:

An Alternative System, Dissertation, Kristianstad Univercity College diakses melalui: http://www.islamicbanking.com

Harif. (2007). Identifikasi faktor penentu keputusan konsumen dalam memilih jasa perbankan: Bank syariah vs bank konvensiona, Hasil Penelitian Bank Indonesia dan Center For Banking Resarch (CBR) Andalas University (tidak diterbitkan).

Hegazy. (1995). Demografic Elemen dan Kriteria Pemilihan Bank (tidak diterbitkan).
James F. Engel dkk. (1994). Consumer Behavior jilid 6. Binarupa Aksara. Jakarta.

Kotler, Philip dan AB. Susanto. 2001. Manajemen Pemasaran.

Terjemahan Hendra Teguh, Ronny A. Rusli dan Benjamin Molan. Jakarta: Edisi Milenium, Prenhallindo.

Outlook Perbankan Syariah 2010. Direktorat Perbankan Syariah. Jakarta.

Salusu, J., (1996). PegambilanKeputusan Stratejik untuk Organisasi Publik danOrganisasi Non Profit. Grasido: Jakarta.

Sarkar, A.A. (1999). Islamic Businis Contract, aency Problem and Theory of Islamic Firm. International Journal of Islamic Finacial Service. Vol.1. No. 2 JulySeptember.

Siagian, Sondang P. (1997).Organisasi, Kepemimpinan, dan Perilaku. Administrasi. Jakarta: PT. Toko Gunung Agung.

Sjahdeini, Sutan Remy. (2007). Perbankan Islam dan Kedudukannya dalam Tata Hukum Perbankan Idonesia. Jakarta. Grafiti

Universitas Brawijaya. (2000). Potensi, preferensi, dan perilaku Masyarakat terhadap bank syariah: Studi pada wilayah propinsi jawa timur. Pusat Pengkajian Bisnis dan Ekonomi Islam Fakultas Ekonomi Universitas Brawijaya (tidak diterbitkan). 